\title{
Magnetic Resonance Imaging of Single Co-Labeled Mesenchymal Stromal Cells after Intracardial Injection in Mice
}

\section{Detektion einzelner doppelt markierter mesenchymaler Stro- mazellen in der Maus mittels MRT nach intrakardialer Injektion}

Authors

Affiliations
J. Salamon ${ }^{1}$, D. Wicklein ${ }^{2}$, M. Didié ${ }^{3}$, C. Lange ${ }^{4}$, U. Schumacher ${ }^{2}$, G. Adam¹, K. Peldschus ${ }^{1}$

Department of Diagnostic and Interventional Radiology, University Medical Center Hamburg-Eppendorf, Hamburg

2 Institute of Anatomy II: Experimental Morphology, University Medical Center Hamburg-Eppendorf, Hamburg

Institute of Pharmacology, University of Goettingen

Department of Bone Marrow Transplantation, University Medical Center Hamburg-Eppendorf, Hamburg
Key words

- magnetic resonance imaging

mesenchymal stromal cells

- SPIO

- intracardial injection

This article was awarded with the Promotionspreis 2013

received $\quad 5.11 .2013$

accepted 16.1.2014

\section{Bibliography}

Dol http://dx.doi.org/ 10.1055/s-0034-1366097

Published online: 2014 Fortschr Röntgenstr 2014; 186: 367-376 @ Georg Thieme Verlag KG Stuttgart · New York ISSN 1438-9029

\section{Correspondence}

\section{Dr. Johannes Salamon}

Klinik und Poliklinik für

Diagnostische und

Interventionelle Radiologie,

Universitätsklinikum Hamburg-

Eppendorf

Martinistraße 52

20246 Hamburg

Germany

Tel.: ++ 49/0 40/7 41054029

Fax: ++ 490 40/7 41053802

j.salamon@uke.de

\section{Zusammenfassung}

$\nabla$

Ziel: Etablierung einer Doppelmarkierung mesenchymaler Stromazellen (MSZ) zur in-vivo Detektion einzelner MSZ mittels MRT und zur histologischen Validierung.

Material und Methoden: Murine MSZ wurden mit fluoreszierenden Eisenmikropartikeln und Carboxyfluorescein Succinimidyl Ester (CFSE) markiert. Der zelluläre Eisengehalt wurde mittels Atomabsorptionsspektrometrie bestimmt. Zellprolieferation und Expression charakteristischer Oberflächenmarker wurden mittels Durchflusszytometrie bestimmt. Die chondrogene Differenzierungskapazität wurde überprüft. Verschiedene Zellanzahlen $(\mathrm{n} 1=5000, \mathrm{n} 2=15000, \mathrm{n} 3=50000)$ wurden bei 12 Mäusen in den linken Herzventrikel injiziert. Es erfolgte die sequenzielle MRT der Tiere an einem klinischen 3.0 T MRT. Zur histologischen Validierung wurden Kryostatschnitte fluoreszensmikroskopisch untersucht.

Ergebnisse: Die magnetische und fluoreszierende Doppelmarkierung von MSZ wurde etabliert (mittlerer zellulärer Eisengehalt 23,6 4,3 pg). Durchflusszytometrisch zeigten sich ähnliche Zellprolieferationsraten und Rezeptorexpressionsprofile von markierten und unmarkierten MSZ. Die chondrogene Differenzierung der doppelt markierten MSZ wurde verifiziert. Nach Zellinjektion zeigten sich im MRT multiple Signalauslöschungen im Hirn und geringer in der Niere. Im Hirn fanden sich durchschnittlich 4,6 \pm $1,2(\mathrm{n} 1), 9,0 \pm 3,6$ (n2) und 25,0 $\pm 1,0$ (n3) Signalauslöschungen pro Schicht. Durchschnittlich fanden sich 8,7 $\pm 3,1$ (n1), 22,0 $\pm 6,1$ (n2) und $89,8 \pm 6,5$ (n3) Zellen pro korrespondierendem Kryostatschnitt. Die statistische Korrelation der mittels MRT detektierten Signalauslöschungen und der histologisch nachgewiesenen Zellen ergab einen Korrelationskoeffizienten von $r=0,91$. Schlussfolgerung: Die Studie zeigt die erfolgreiche magnetische und fluoreszierende Doppelmarkie-

\section{Abstract \\ $\nabla$}

Purpose: The aim of this study was to establish co-labeling of mesenchymal stromal cells (MSC) for the detection of single MSC in-vivo by MRI and histological validation.

Materials and Methods: Mouse MSC were co-labeled with fluorescent iron oxide micro-particles and carboxyfluorescein succinimidyl ester (CFSE). The cellular iron content was determined by atomic absorption spectrometry. Cell proliferation and expression of characteristic surface markers were determined by flow cytometry. The chondrogenic differentiation capacity was assessed. Different amounts of cells $(\mathrm{n} 1=5000, \mathrm{n} 2=$ $15000, n 3=50000$ ) were injected into the left heart ventricle of 12 mice. The animals underwent sequential MRI on a clinical 3.0 T scanner (Intera, Philips Medical Systems, Best, The Netherlands). For histological validation cryosections were examined by fluorescent microscopy.

Results: Magnetic and fluorescent labeling of MSC was established (mean cellular iron content 23.6 \pm $3 \mathrm{pg})$. Flow cytometry showed similar cell proliferation and receptor expression of labeled and unlabeled MSC. Chondrogenic differentiation of labeled MSC was verified. After cell injection MRI revealed multiple signal voids in the brain and fewer signal voids in the kidneys. In the brain, an average of $4.6 \pm 1.2(\mathrm{n} 1), 9.0 \pm 3.6(\mathrm{n} 2)$ and $25.0 \pm$ 1.0 (n3) signal voids were detected per MRI slice. An average of $8.7 \pm 3.1(\mathrm{n} 1), 22.0 \pm 6.1$ (n2) and $89.8 \pm 6.5$ (n3) labeled cells per corresponding stack of adjacent cryosections could be detected in the brain. Statistical correlation of the numbers of MRI signal voids in the brain and single MSC found by histology revealed a correlation coefficient of $r=0.91$.

Conclusion: The study demonstrates efficient magnetic and fluorescent co-labeling of MSC and their detection on a single cell level in mice by in- 
rung von MSZ und deren Detektion auf Einzelzellniveau mittels in vivo MRT und Histologie. Die beschriebenen Techniken tragen zur Erweiterung der Methoden für das in vivo Monitoring von MSZ bei. Kernaussagen:

- Die Detektion einzelner magnetisch markierter Zellen in vivo im 3,0 T MRT ist möglich.

- Die magnetische und Fluoreszenzmarkierung haben keinen negativen Einfluss auf die Zellvitalität.

- Die Anzahl mittels MRT und Histologie detektierter Zellen zeigt eine hohe Korrelation. vivo MRI and histology. The described techniques may broaden the methods for in-vivo tracking of MSC.

Key Points:

- Detection of single magnetically labeled MSC in-vivo using a clinical 3.0 T MRI is possible.

- Fluorescent and magnetic co-labeling does not affect cell vitality.

- The number of cells detected by MRI and histology has a high correlation.

Citation Format:

- Salamon J, Wicklein D, Didié M et al. Magnetic Resonance Imaging of Single Co-Labeled Mesenchymal Stromal Cells after Intracardial Injection in Mice. Fortschr Röntgenstr 2014; 186: 367-376

\section{Introduction}

Magnetic resonance imaging (MRI) of magnetically labeled cells is a powerful technique for the noninvasive detection and tracking of specific cell cohorts after local or systemic administration. Migration of lymphocytes [1], hematopoetic stem cells [2], mesenchymal stromal cells [3], neuronal precursor cells [4] and tumor cells [5] has been demonstrated in different disease models by in-vivo MRI. The size of iron oxide particles successfully applied for cell labeling ranges from very small particles [6] to micron-sized particles [7] of which the medium-sized superparamagnetic particles of iron oxide (SPIO), such as the clinically approved iron oxide contrast agents, are typically used for magnetic cell labeling [8]. Furthermore, labeling approaches vary in terms of cell incubation and the possible use of transfection agents [9]. All the different magnetic labeling techniques result in a considerable increase of the cellular iron content up to 100 pg per cell [7] compared to a physiological cellular iron content of generally less than $1 \mathrm{pg}$ [10]. The large amount of intracellular iron oxide particles and the use of high-resolution $\mathrm{T}^{*}$ weighted gradient echo sequences permits cellular MRI techniques to be very sensitive. Thus, MRI of single magnetically labeled cells could be demonstrated in-vitro [11] and promising results have been shown also in-vivo, e.g. the detection of single macrophages in the brain after intracardial injection [12] and migration of hepatocytes to the liver after injection into the spleen [13].

Multipotent mesenchymal stromal cells (MSC), also known as mesenchymal stem cells [14], are bone marrow-derived precursor cells with the potential to differentiate into different mesenchymal lineages, such as adipocytes, chondroblasts and osteoblasts [15]. Because of their differentiation potential, MSC are of particular interest for cell-based therapies in different acute disorders such as myocardial infarction and acute renal failure $[16,17]$. Furthermore, MSC are known for their immunosuppressive and immunomodulatory potential during stem cell transplantation [18-21]. They show a considerable rescue potential after lethal irradiation [22] or chemotherapy [23]. Several studies show their positive impact on wound healing, bone, cartilage and tendon repair in clinical settings [24-27]. Recently, Karussis et al. showed that transplantation of MSCs in patients with MS and ALS is a clinically feasible and relatively safe procedure and induces immediate immunomodulatory effects [28]. Even though MSC are known to deliver local growth factors for the regulation of hematopoesis, the exact mechanism of their positive modulatory impact in peripheral organs after either local or systemic ap- plication remains unclear [29-31]. The efficacy of such therapies could be in part monitored by cellular MRI. Cell tracking of large cohorts of magnetically labeled MSC has been demonstrated in rat models of nephropathy after intravenous [32] and intraarterial [33] injection and after intramyocardial cell injection in a porcine model of myocardial infarction [34]. Furthermore, at least four clinical trials using MRI cell tracking with superparamagnetic iron oxides have been performed with promising results and it is most likely that MSC-based therapies will become more and more popular over the next decades [35, 36]

This study investigates the possibility of in-vivo single cell detection of MSC by MRI, which would be a valuable technique to track the migration of even small numbers of MSC in living animals and may help to improve the understanding of the timeline of cell-based therapies, the cells immediate and long-term fate as well as the exclusion of graft failure or tumor formation at the injection side [37]. Therefore, the aims of this study were I) to magnetically and fluorescently co-label MSC, II) to detect co-labeled MSC by in-vivo MRI after minimally invasive intracardial injection of cells in mice and III) to validate MRI findings by verification of single cell distribution in different organs by fluorescent microscopy.

\section{Materials and Methods}

$\nabla$

\section{Cell culture}

The murine mesenchymal stromal cells were a generous gift by PD Dr. rer. nat. C. Lange. The cells were generated from the bone marrow of three male adult $\mathrm{C} 57 \mathrm{Bl} / 6$ mice by standard methods [38] and grown adherent in standard $T 75$ flasks for more than 10 passages to confirm phenotype and purity. For the culture medium DMEM/Ham's F-12 medium (Biochrom, Berlin, Germany) supplemented with $20 \%$ fetal calf serum (Gibco, Karlsruhe, Germany), 2 mol/l L-glutamine, $100 \mathrm{U} / \mathrm{ml}$ penicillin and $100 \mathrm{mg} /$ $\mathrm{ml}$ streptomycin (Gibco, Karlsruhe, Germany) was used.

\section{Cell labeling}

MSC were incubated overnight with red fluorescent, superparamagnetic iron oxide micro-particles with a mean diameter of $1.63 \mu \mathrm{m}$, containing a magnetite core encapsulated with the fluorochrome "Suncoast Yellow" (Ex: $540 \mathrm{~nm} / \mathrm{Em}$ : $600 \mathrm{~nm}$ ) and a dextran shell (Banglabs, Fishers, IN, USA). The effective iron concentration of the culture medium was $25 \mu \mathrm{g} / \mathrm{ml}$. The cells underwent three steps of washing with phosphate buffered saline (PBS) before they were trypsinized, reseeded in a new culture 
flask and grown overnight. The next day, the cells were washed repeatedly until no particles could be detected in the supernatant by conventional inverse fluorescence microscopy. Subsequently, MSC were incubated with green fluorescent carboxyfluorescein succinimidyl ester (CFSE) from CellTrace ${ }^{\mathrm{TM}}$ CFSE Cell Proliferation Kit (Invitrogen, Karlsruhe, Germany) at a concentration of $1.5 \mu \mathrm{l} /$ $\mathrm{ml}$ in serum free culture medium for 20 minutes. The reaction was stopped by washing three times with ice cold PBS.CFSE only dyes living cells since it is intracellulary activated by esterases and covalently linked to intracellular proteins. With the achieved double color fluorescent labeling it was possible to differentiate intact MSC from particles accumulated in phagocytes.

\section{Determination of the cellular iron content}

Labeled as well as unlabeled cells at samples of $1 \times 10^{4}, 5 \times 10^{4}$ and $1 \times 10^{5}$ were lysed at room temperature in $500 \mu$ suspension of 0.02 molar nitric acid and Triton X 100 (Sigma Aldrich, Saint Louis, MI, USA) for 15 minutes. These suspensions were roughly vortexed. To calculate the mean cellular iron content three measurements were taken from different cell samples using an atomic absorption spectrometer (Perkin Elmer 2100, Norwalk, CT, USA).

\section{Flow cytometry analysis}

On day five after cell labeling, the cells were suspended with cell dissociation buffer (Invitrogen, Karlsruhe, Germany), counted and resuspended in PBS containing $1 \%$ bovine serum albumin and $0.05 \% \mathrm{NaN}_{3}$ as the buffer for staining and washing. To compare the surface marker expression of CD44 +, CD90 +, CD105 +, Sca-1+, CD34- and CD45- of co-labeled MSC to the marker expression of unlabeled MSC, the following monoclonal antibodies and isotype controls were used: biotinylated rat anti-mouse antibodies for CD34, CD44, CD45, CD90 and Sca-1 and appropriate biotinylated isotype IgG followed by streptavidin-allophycocyanin (all BD Biosciences, Heidelberg, Germany), rat anti-mouse antibody CD105 / Endoglin-Allophycocyanin and rat IgG2a-allophycocyanin isotype control (R\&D Systems, Wiesbaden, Germany). A living / dead cell differentiation was performed using propidium iodide that permeates the cell membrane of dead cells leading to an intracellular accumulation of the dye (Sigma-Aldrich, St.Louis, MO). Roughly $40 \%$ of events were excluded in each sample using a combination of the forward and sideward scatter as well as reactivity to propidium iodide to exclude cell debris and dying cells from measurements.

To determine a potential influence of iron oxide micro-particles on the cell proliferation, the CFSE signal of co-labeled MSC was compared to the CFSE signal of MSC labeled with CFSE only. For all measurements a FACSCalibur cytometer (BD Biosciences, Heidelberg, Germany) and Win MDI 2.9 software for data analysis were used.

\section{Chondrogenic differentiation assay}

Co-labeled MSC were resuspended in $2 \%$ alginic acid (Sigma-Aldrich, St.Louis, MO) at a cell density of $1.5 \times 10^{6}$ cells / ml. Following standard procedures [39], the cells were dropwise gelatinized in $0.1 \mathrm{M} \mathrm{CaCl}_{2}$ (Merck, Darmstadt, Germany). The consequently newly formed alginate spheres were incubated in culture medium for 7 days, then fixed in $10 \%$ formalin for 1 hour. Before staining in $0.05 \%$ acidic Alcian Blue and $4 \% \mathrm{MgCl}_{2}$ solution (all SigmaAldrich, St.Louis, MO) for $24 \mathrm{~h}$, the spheres were washed in $2 \%$ acetic acid. After dehydration with ascending ethanol series and finally xylol, the spheres were embedded with Entellan (both, Merck, Darmstadt, Germany) under slight pressure. Control pre- parations were fixed, stained and embedded immediately after gelatinization to exclude expression of proteoglycans on nonstimulated co-labeled MSC.

\section{Intracardial injection}

Animal procedures were approved by the institutional animal care committee. Labeled MSC were prepared at concentrations of $1 \times 10^{5}, 3 \times 10^{5}$ and $1 \times 10^{6}$ cells $/ \mathrm{ml}$ in serum free culture medium. For the injection $50 \mu \mathrm{l}$ cell suspension in a $250 \mu \mathrm{l}$ glass syringe (Hamilton AG, Bonaduz, Switzerland) with a 30-gauge needle (Braun AG, Melsungen, Germany) was used. Cells were injected into the left ventricle of the heart using ultrasound guidance with a $30 \mathrm{MHz}$ center frequency single element ultrasound transducer of a Vevo 770 Microimaging System (VisualSonics Inc., Toronto, Canada). For the procedure the animals were anesthetized with a $1-1.5 \%$ isoflurane/air mixture. A total of 12 mice received intracardial injections. According to the cell concentrations and the injection volume mentioned above, 5000 (n1), 15000 (n2) and 50000 (n3) MSC as well as serum-free culture medium without cells were injected into 3 mice per group.

\section{MR imaging}

The MR sequence protocol consisted of T1-weighted localizers in three orthogonal planes, an additional T2-weighted localizer in sagittal orientation and high-resolution $\mathrm{T} 2{ }^{*}$-weighted $3 \mathrm{D}$ and $2 \mathrm{D}$ coherent gradient-echo sequences to examine the brain and the abdomen, respectively. The sequence parameters of the high-resolution $3 \mathrm{D}$ gradient-echo sequence to examine the brain were as follows: TR / TE / FA=30 ms / $15 \mathrm{~ms} / 15^{\circ}$; field-of-view $(\mathrm{FOV})=22 \times 22 \mathrm{~mm}^{2}$; matrix $=112 \times 112$; slice thickness $(\mathrm{ST})=$ $0.2 \mathrm{~mm}$, number of slices $(\mathrm{NS})=55$; number of acquisitions $(\mathrm{NA})=4$; acquisition time $=15$ minutes 41 seconds. The sequence parameters of the high-resolution $2 \mathrm{D}$ gradient-echo sequence for the abdomen were as follows: TR / TE / FA = 30 ms / $15 \mathrm{~ms} / 15^{\circ}$; FOV $=22 \times 22 \mathrm{~mm}^{2}$; matrix $=112 \times 112 ; \mathrm{ST}=0.5 \mathrm{~mm}$, number of slices NS $=40$; number of acquisitions $(N A)=4$; acquisition time $=12$ minutes 23 seconds. The spatial resolution was $200 \times 200 \times 200 \mu^{3}$ for the $3 \mathrm{D}$ gradient-echo sequence and $200 \times 200 \times 500 \mu \mathrm{m}^{3}$ for the $2 \mathrm{D}$ gradient-echo sequence. The MR sequence protocol was tested using cell phantoms. For preparation, $1 \mathrm{ml}$ with different numbers of co-labeled MSC resuspended in PBS were gently mixed with $4 \mathrm{ml} 10 \%$ gelatin (180 bloom, Carl Roth $\mathrm{GmbH}$, Karlsruhe, Germany) in $5 \mathrm{ml}$ round bottom tubes to reveal phantoms with cell densities of 2500, 500, and 100 MSC / $\mathrm{ml}$. The phantoms were placed horizontally in the solenoid mouse coil for MR imaging. The mice underwent MRI the day before and five hours after the intracardial cell injection. The interval of five hours was due to the scheduling of cell injections and MRI consecutively for several animals per day. The animals were anesthetized for the imaging procedure with intraperitoneal injection of ketamine / xylazine. The signal-to-noise-ratio (SNR) and the detection of small signal voids were analyzed. By manually placing elliptical regions-of-interest (ROI) with a size of $10 \mathrm{~mm}^{2}$ in source images of the brain, liver, spleen and kidneys, the SNR was calculated measuring the signal intensity (SI). Noise was determined as standard deviation (SD) of SI in an ROI with a size of $100 \mathrm{~mm}^{2}$ placed in the air adjacent to the lower abdomen to obviate phase-related artifacts from respiratory motion. SNR = [SI structure - SI noise ] / SD SI noise. Furthermore, clearly circumscribed signal voids were counted in the different organs and mean numbers per slice were calculated. 
All scans were performed on a clinical 3.0 T MRI, equipped with a conventional body transmit coil and gradient system allowing a maximal amplitude of $30 \mathrm{mT} \mathrm{m} \mathrm{m}^{-1}$ and a slew rate of $50 \mathrm{mT}^{-1} \mathrm{~s}^{-1}$ (Intera, Philips Medical Systems, Best, The Netherlands). For signal reception a dedicated solenoid mouse body coil with an inner diameter of $3 \mathrm{~cm}$ and a length of $7 \mathrm{~cm}$ was used (Philips Research Laboratories, Hamburg, Germany).

\section{Histological analysis}

The mice were sacrificed by cervical dislocation under $\mathrm{CO}_{2}$ anesthesia within 7 hours after cell injection. The brain, liver, spleen, kidneys and lungs were embedded in Tissue-Tek (Sakura Finetek, Heppenheim, Germany) and snap frozen in liquid nitrogen. For preparation of cryosections with a thickness of $10 \mu \mathrm{m}$ a cryostat microtome (Leica, Wetzlar, Germany) was used. The cryosections were fixed in $4 \%$ paraformaldehyde, counterstained and covered with a 4,6-Diamono-2phenylindol (DAPI) containing mounting medium (Vectashield mounting medium Vector Laboratories, Inc. Burlingame, CA). A universal microscope (Axio Phot 2, Carl Zeiss Microimaging, Goettingen, Germany) was used for large field fluorescence and phase contrast microscopy, and selected cryosections were examined on a confocal microscope (Carl Zeiss Microimaging, Goettingen, Germany).

\section{Statistical analysis}

Measurements of SNR in different organs before and after cell injections were compared using the paired student's t-test. The level of significance was assumed for $\mathrm{p}<$ or $=0.05$. For statistical correlation of the numbers of MRI signal voids and single MSC found on histology, the Pearson's product-moment coefficient was used.

\section{Results}

\section{$\nabla$}

\section{Labeling and characterization of cells}

The co-labeling of MSC with iron oxide micro-particles and CFSE revealed a perinuclear accumulation of red fluorescent micro-particles and green fluorescence of the cytoplasm as shown by confocal microscopy ( $\bullet$ Fig. 1a). Single co-labeled MSC could be detected in MRI phantoms using both high-resolution T2*-weighted $3 \mathrm{D}$ and 2 D GRE sequences ( $\bullet$ Fig. 1b). Atomic absorption spectrometry revealed a mean cellular iron content of $23.6 \pm 4.3 \mathrm{pg}$ after cell labeling compared to $0.4 \pm 0.1 \mathrm{pg}$ of unlabeled cells. Flow cytometry showed a similar cell proliferation for MSC labeled with CFSE and iron oxide micro-particles compared to MSC labeled with CFSE only ( $\bullet$ Fig. 2a). After five days CFSE could not be reliably detected anymore in both cell cohorts due to dilution of the dye as a result of cell division. Expression of CD44, CD90, CD105 and Sca-1 as well as negativity of CD34 and CD45 (data not shown) was demonstrated in unlabeled MSC and in MSC labeled with CFSE and iron oxide micro-particles ( $\bullet$ Fig. 2b). Chondrogenic differentiation indicated by positive staining for glycosaminoglycans with Alcian Blue was observed for co-labeled MSC within 7 days whereas co-labeled MSC without stimulation showed no Alcian Blue staining ( $\bullet$ Fig. 3).

\section{In-vivo cell imaging}

Intracardial injections of MSC were successful in all animals. Echocardiographic control after intracardial injection ( $\bullet$ Fig.4) did not show pericardial fluid or other complications. MRI of the brain using the high-resolution $\mathrm{T} 2 *$-weighted $3 \mathrm{D}$ GRE sequence revealed the occurrence of multiple sharply defined signal voids throughout the entire brain with the highest cell density in the vascular territory of the medial cerebral artery ( $\bullet$ Fig. 5). The high-resolution $\mathrm{T} 2 *$-weighted $2 \mathrm{D}$ gradient-echo sequence of the abdomen showed the occurrence of a few signal

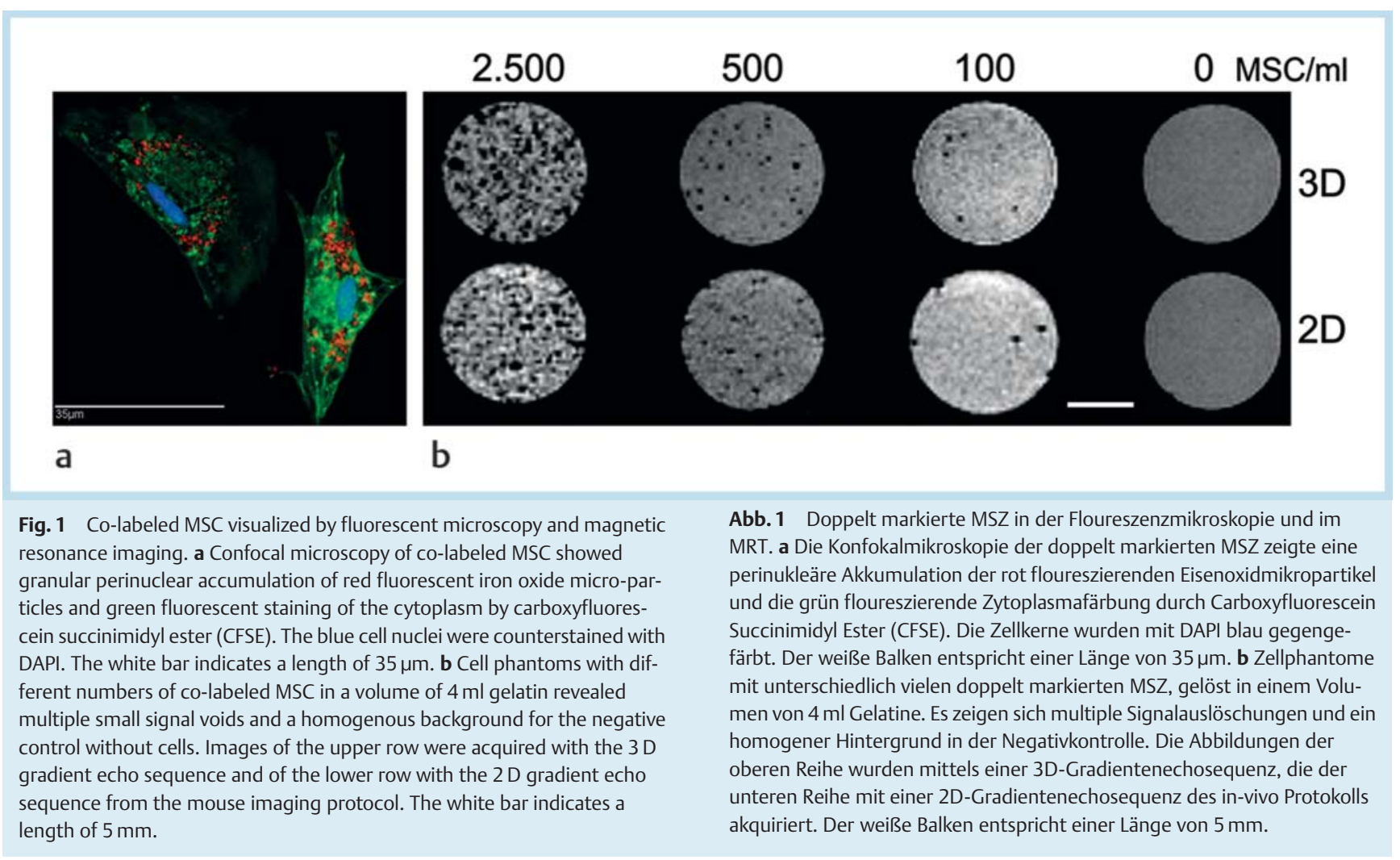




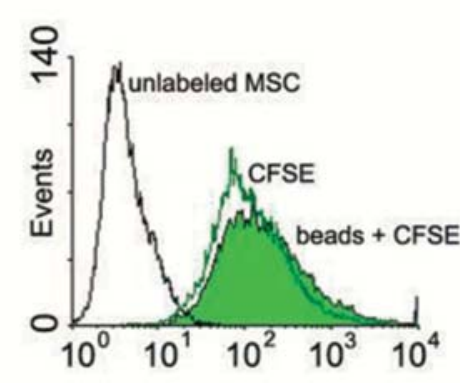

a
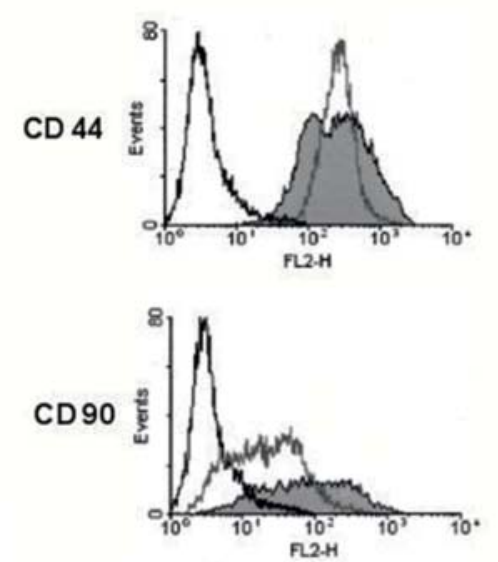

CD 105
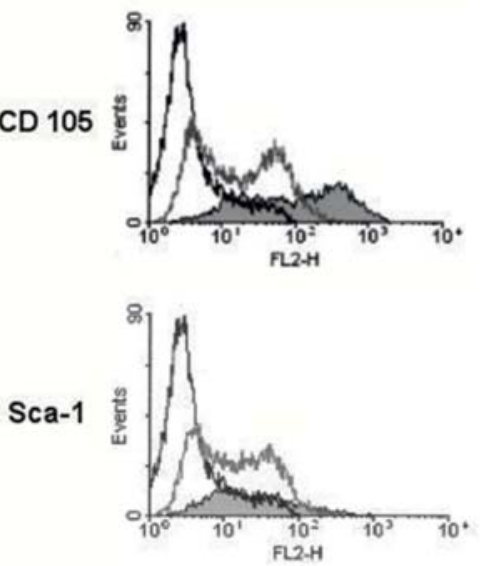

Fig. 2 Characterization of co-labeled MSC by flow cytometry. a Cell proliferation within five days determined by measurements of the CFSE signal was similar for MSC labeled with CFSE and iron oxide micro-particles compared to that of MSC labeled only with CFSE. $\mathbf{b}$ Expression of typical cell surface markers CD44, CD90, CD105 and Sca-1 was demonstrated for unlabeled MSC (white areas under the curve) and co-labeled MSC (gray areas under the curve), compared to a standard isotype control.
Abb. 2 Durchflusszytometrische Charakterisierung doppelt markierter MSZ. a Die Zellproliferation in den ersten fünf Tagen, gemessen am CFSE-Signal, war bei CFSE-markierten und CFSE- und Eisenoxidmikropartikel-doppelt markierten MSZ gleich. b Die Expression der typischen Zelloberflächenmarker CD44, CD90, CD105 und Sca-1 dargestellt für unmarkierte MSZ (weiße Flächen unter den Kurven) und doppelt markierte MSZ (graue Flächen unter den Kurven) im Vergleich mit einer Standard Isotypenkontrolle.
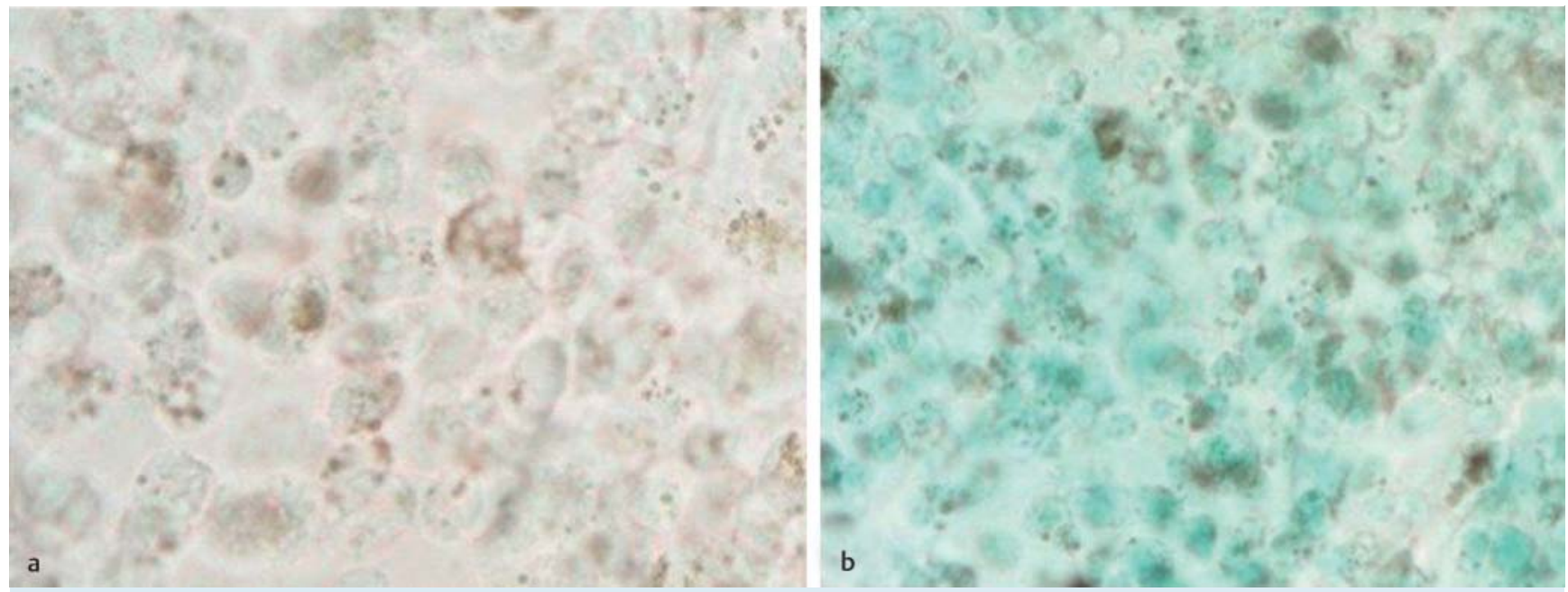

Fig. 3 Chondrogenic differentiation of co-labeled MSC. a Co-labeled MSC without stimulation revealed no Alcian Blue staining for glycosaminoglycan. b Positive staining for glycosaminoglycan with Alcian Blue after culture of co-labeled MSC in alginate spheres for 7 days.

Abb. 3 Chondrogene Differenzierung von doppelt markierten MSZ. a Doppelt markierte MSZ ohne Stimulation zeigen keine Blaufärbung für Glykosaminoglykane. b Positive Färbung auf Glycosaminoglykane mittels Alcian Blau nach 7 tägiger Kultur in Alginatsphären.

voids in the kidneys ( $\bullet$ Fig. $\mathbf{6}$ ). In the liver and spleen similar signal voids could not be detected. Smaller parenchymal organs such as the pancreas and adrenal glands as well as the heart were not well detectable due to motion artifacts. In air-containing intestinal organs as well as the lungs, the detection of magnetically labeled cells was impossible due to the low signal background. Analysis of signal intensity measurements revealed a significant difference of mean SNR values in the brain before and after injection of 50000 cells and no significant difference for other cell numbers and organs ( $\bullet$ Table 1 ). Quantitative analysis of signal voids in the brain resulted in an average of $4.6 \pm 1.2(\mathrm{n} 1), 9.0 \pm 3.6(\mathrm{n} 2)$ and $25.0 \pm 1.0$ (n3) signal voids per axial MRI slice.

\section{Histological analysis}

Microscopy of cryosections revealed trapping of single MSC in the brain, lung, liver, spleen and kidneys ( $\bullet$ Fig. 7). Single MSC could be well depicted by confocal microscopy due to the co-labeling with CFSE and micro-particles as green and red fluorescent spots ( $\bullet$ Fig. 8). Furthermore, red fluorescent micro-particles could be detected in the spleen ( $\boldsymbol{Q}$ Fig. 7 ) and liver (not shown). The quantitative analysis of brain sections revealed an average of $8.7 \pm 3.1$ (n1), $22.0 \pm 6.1$ (n2) and $89.8 \pm 6.5$ (n3) MSC per stack of 20 adjacent cryosections (each with a thickness of $10 \mu \mathrm{m})$. Statistical correlation of the numbers of MRI signal voids and single MSC found on histology revealed a correlation coefficient of $r=0.91$. 

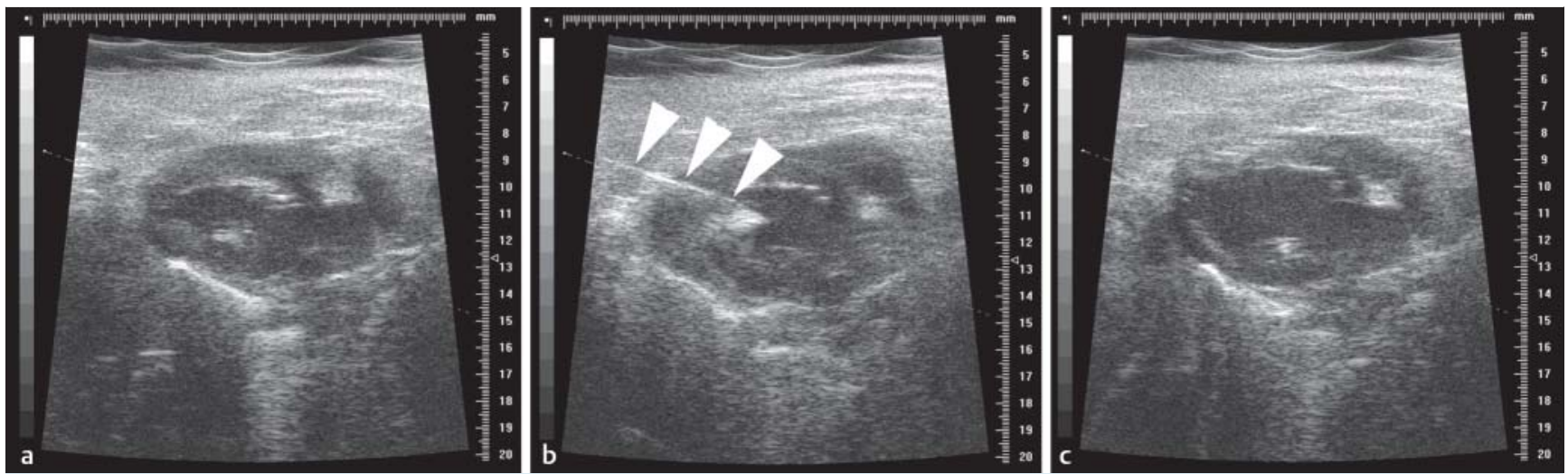

Fig. 4 Intracardial injection of labeled MSC guided by high-resolution ultrasound. Images represent parasternal views of the left ventricle before injection $\mathbf{a}$, with the needle inserted into the left ventricle indicated as echogenic oblique line (white arrowheads) in the upper left quadrant $\mathbf{b}$ and after retraction of the needle $\mathbf{c}$. Pericardial fluid was not observed.
Abb. 4 Ultraschallgesteuerte intrakardiale Injektion markierter MSZ. Die Abbildungen zeigen einen parasternalen Schnitt des linken Ventrikels vor der Injektion a, mit der Nadel im linken Ventrikel, die sich als echoreiche schräge Linie (weiße Pfeilspitzen) im oberen linken Quadranten darstellt b und nach Rückzug der Nadel c. Es wurde kein Perikarderguss beobachtet.

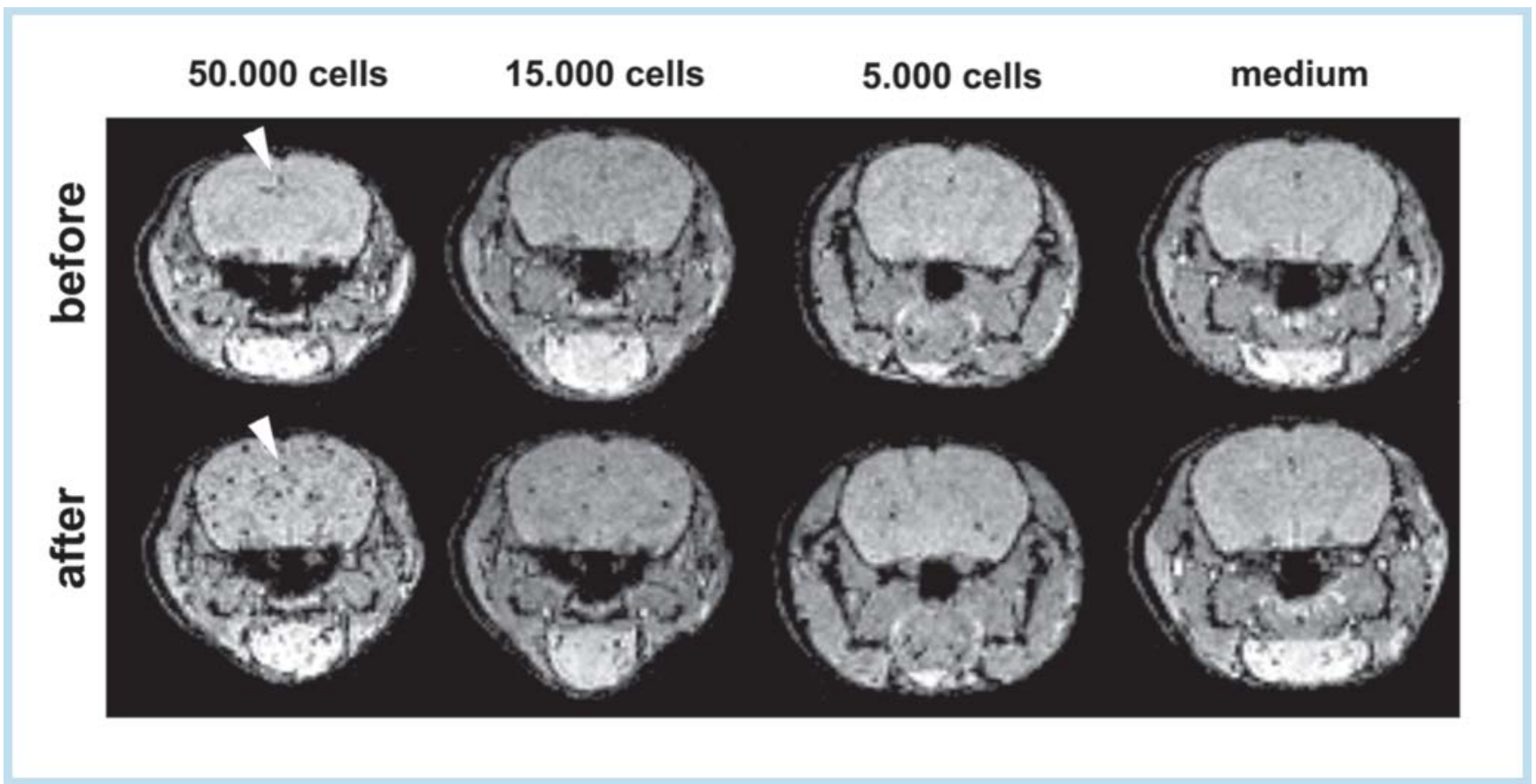

Fig. 5 Magnetic resonance imaging of the brain in prone position before and after cell injection of different numbers of co-labeled MSC. Trapping of cells in the brain after intracardial injection was demonstrated by the presence of small signal voids similar to imaging of cell phantoms ( 0 Fig. $1 \mathbf{b}$ ). Controls with injection of an equivalent amount of culture medium did not reveal such signal voids except the superior sagittal sinus (white arrow head).
Abb.5 Magnetresonanztomografie des Hirns in Bauchlage vor und nach der Injektion verschiedener Zellanzahlen doppelt markierter MSZ. Die Anwesenheit der Zellen im Hirn zeigt sich durch kleine Signalauslöschungen, welche auch in den Zellphantomen sichtbar waren (vergleiche $\square$ Abb. 1b). In Kontrolltieren, denen eine äquivalente Menge Kulturmedium injiziert wurde, zeigten sich, außer im Sinus sagittalis superior (weiße Pfeilspitze), keine Signalauslöschungen.

\section{Discussion}

In this study co-labeling of MSC with fluorescent superparamagnetic iron oxide micro-particles and CFSE could be demonstrated. The use of these large iron oxide mirco-particles for magnetic cell labeling was initially described by Shapiro et al. [7]. The crucial advantage of these micro-particles is their pronounced $\mathrm{T} 2 *$ effect due to the large iron oxide core, allowing even single micro-particles to be detected by MRI [40] which is preferable for single cell imaging. In addition to the fluorescent micro-particles, MSC were also labeled with CFSE, a common fluorescent dye for cytoplasmic label-

ing of cells. The intake of two fluorescent dyes in MSC was beneficial for histological detection of MSC in cryosections and to distinguish them from scavenger cells that take up released micro-particles ( $\bullet$ Fig. 7). The possible influence of the co-labeling on cell viability, expression of characteristic cell surface markers and chondrogenic differentiation was especially addressed. To show the correct phenotype and the purity of MSC, the presence of typical cell surface markers such as CD44, CD90, CD105 and Sca-1 was verified [38]. To exclude hematopoetic differentiation, negativity of CD34 and CD45 was shown. After co-labeling of MSC 


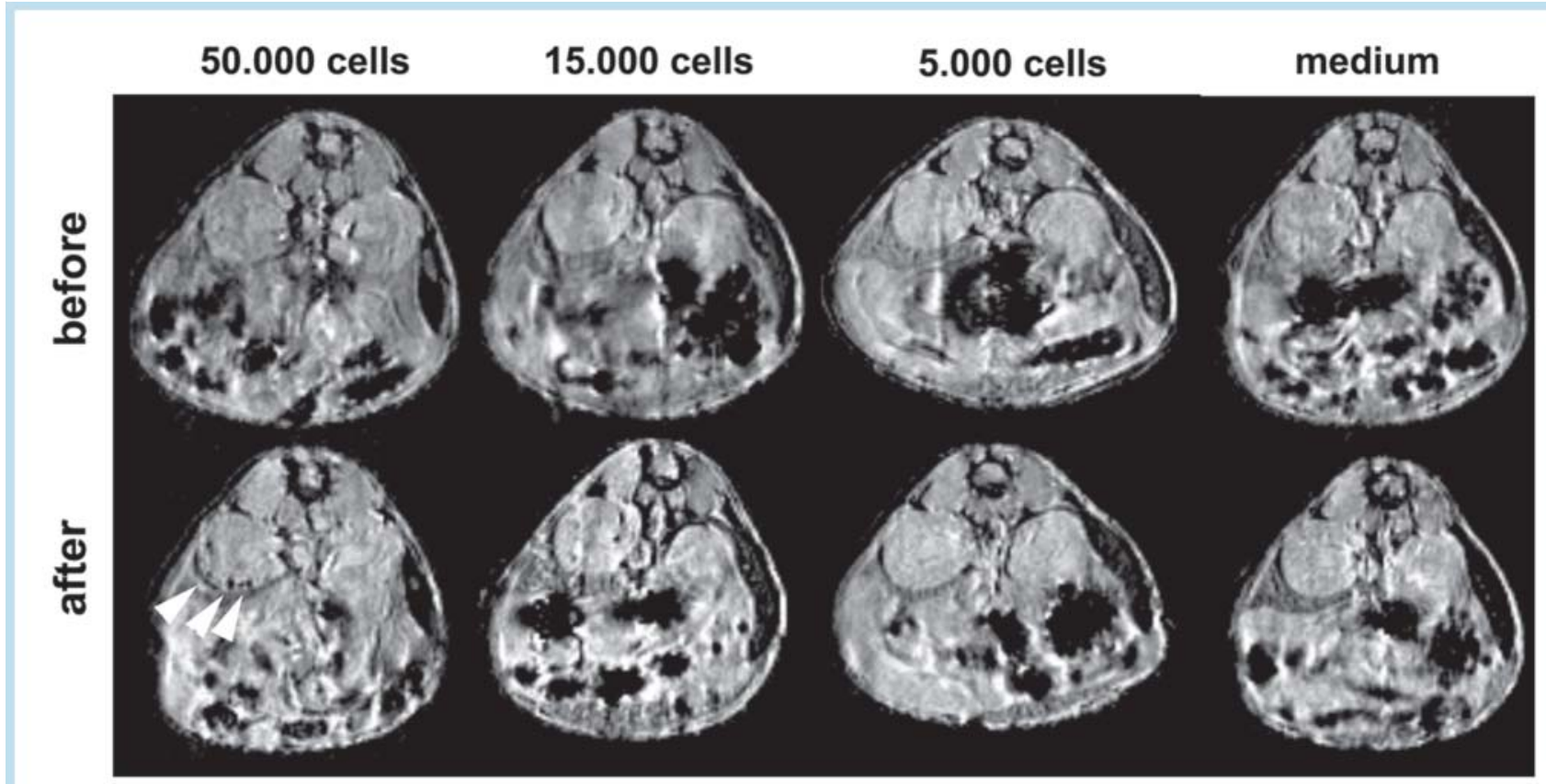

Fig. 6 Magnetic resonance imaging of the abdomen in prone position before and after injection of different numbers of co-labeled MSC. Trapping of cells in abdominal organs indicated by small signal voids (white arrowheads) could be only observed in the kidneys of animals receiving 50000 cells. The blurred appearance of intestinal organs was due to shallow respiratory motion.
Abb. 6 Magnetresonanztomografie des Abdomens in Bauchlage vor und nach der Injektion verschiedener Zellanzahlen doppelt markierter MSZ. Die Anwesenheit von Zellen in den abdominalen Organen konnte durch kleine Signalauslöschungen (weiße Pfeilspitzen) nur in den Nieren der Tiere nachgewiesen werden, denen 50000 Zellen injiziert wurden. Die unscharfe Abbildung der Organe ist auf Atmungsartefakte zurückzuführen. with iron oxide micro-particles and CFSE, the cell proliferation was similar to that of MSC labeled only with CFSE and expression of characteristic surface markers mentioned above could be confirmed. Another important issue was the differentiation capacity of co-labeled MSC. Different studies have shown that osteogenic and adipogenic differentiation of MSC is not affected by magnetic labeling, but considering contradictory results for chondrogenic differentiation $[41,42]$, this seems to be sensitive to cellular iron uptake. Therefore, the chondrogenic differentiation capacity was investigated for co-labeled MSC. Results revealed a positive induction within 7 days, demonstrated by staining of cartilage-specific proteogylcans. A mean cellular iron content of $24 \mathrm{pg}$ was found in co-labeled MSC, this finding was similar to reported values for magnetic cell labeling without toxic effects [10, 41, 43]. Therefore, it was assumed that the co-labeling approach described above was an applicable method to study MSC in-vivo by MRI and to validate their localization by histology.

In the in-vivo experiments the detection of single co-labeled MSC could be demonstrated by MRI. For a systemic delivery and peripheral single cell distribution bypassing the lung barrier [44], the MSC were injected into the left ventricular cavity of the heart as described for magnetically labeled macrophages by Heyn et al. [12]. However, instead of a surgical method with an open-chest incision, a minimally invasive ultrasound-guided approach was used. All animals survived the procedure of intracardial cell injection. No complications were observed after the administration of cells and during sacrifice. A comparable technique for intramyocardial injection in mice was also described as a safe procedure [45]. Comparable to macrophages, MSC are relatively large cells with a mean diameter of $15-19 \mu \mathrm{m}$ in suspension and thus trapping of single cells can be seen in small vessels and capillaries after systemic administration [44]. However, in this study a reliable detection of MSC in-vivo by MRI was only possible in the brain, where multiple sharply defined signal voids could be detected. The corresponding histological sections showed multiple single co-labeled MSC in the brain tissue ( $\bullet$ Fig. 7, 8). In the abdomen, MRI revealed only a few small signal voids in the kidneys indicating the presence of single co-labeled MSC which was confirmed on histological sections. However, histological analysis also revealed single co-labeled MSC in the liver, spleen and lungs ( $\bullet$ Fig. 7) indicating the ubiquitary distribution of single MSC after intracardial injection.

Analysis of SNR values ( $\bullet$ Table 1 ) did not show significantly different results for the investigated organs before and after the injection of MSC with the exception of the highest cell density in the brain after the administration of 50000 cells. Thus, it might be assumed that a few MSC visible as small signal voids on highresolution MR imaging cannot be reliably detected using conventional SNR evaluation in a reasonable region-of-interest due to the partial volume effect of the surrounding tissue. The slightly increased SNR values after cell injection in the group of mice that received 5000 cells were caused by motion artifacts due to suboptimal anesthesia of one animal. However, these variances appeared in the range of SNR measurements in the other groups and were not statistically significant.

A limiting factor during imaging of the abdomen was respiratory motion. Thus, the high-resolution 3D GRE sequence applied for imaging of the brain could not be used for imaging of the abdomen. Instead, a 2 D GRE sequence was applied for examination of abdominal organs. Although the $2 \mathrm{D}$ GRE sequence had the same inplane resolution of $200 \times 200 \mu \mathrm{m}$, the slice thickness was restricted to $500 \mu \mathrm{m}$ according to the minimally adjustable value of the clin- 


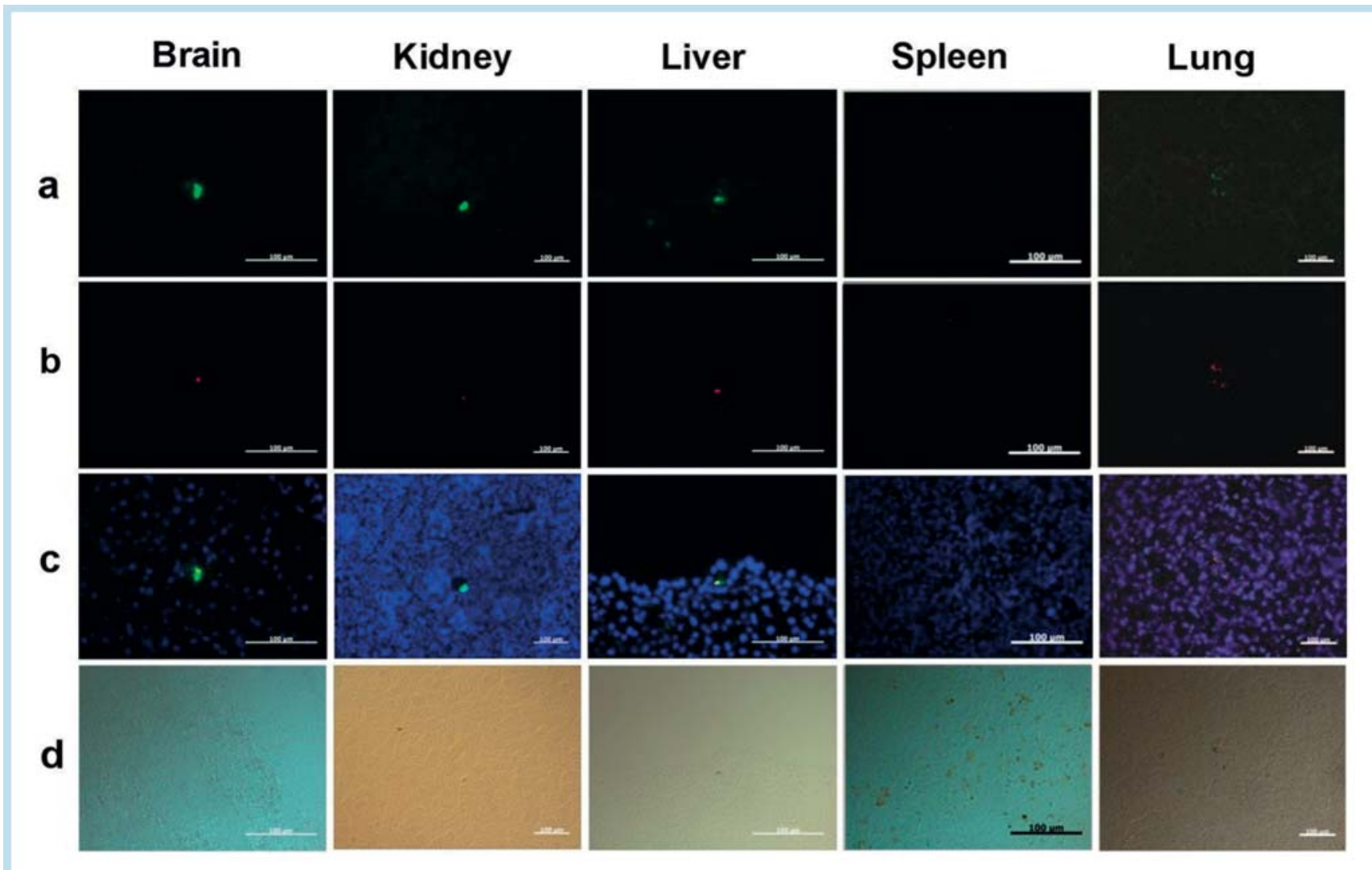

Fig. 7 Fluorescent and phase contrast microscopy of co-labeled MSC in different organs. Co-labeled MSC could be identified by green CFSE stained cytoplasm a and red fluorescent micro-particles $\mathbf{b}$. Counterstain with DAPI c and phase contrast images $\mathbf{d}$ demonstrate tissue specific environment in the different organs. The single MSC in the kidney is localized on a vessel wall, indicating trapping of MSC in small vessels. Notably, released red flourescent micro-particles most likely taken up by scavenger cells can be seen in vcinity of the single MSC in the spleen. The white bars indicate a length of $100 \mu \mathrm{m}$.
Abb.7 Floureszenz- und Phasenkontrastmikroskopie doppelt markierter MSZ in verschiedenen Organen. Doppelt markierte MSZ wurden durch grün CFSE-gefärbtes Zytoplasma a und rot floureszierende Mikropartikel b identifiziert. Gegenfärbung mit DAPI $\mathbf{c}$ und Phasenkontrastmikroskopie $\mathbf{d}$ zeigen die gewebsspezifische Umgebung der verschiedenen Organe. Die einzelne MSZ in der Niere ist an einer Gefäßwand lokalisiert, dies deutet daraufhin, dass die Zellen in kleinen Gefäßen gefangen sind. Bemerkenswert sind freigewordene rot floureszierende Mikropartikel, die in der Umgebung der einzelnen MSZ in der Milz sichtbar sind und am ehesten von Makrophagen aufgenommen wurden. Der weiße Balken entspricht einer Länge von $100 \mu \mathrm{m}$.

\begin{tabular}{|c|c|c|c|c|c|c|c|}
\hline $\begin{array}{l}\text { number of } \\
\text { cells }\end{array}$ & injection & brain & liver & spleen & left kidney & right kidney & $\begin{array}{l}\text { Table } 1 \text { Means } \pm \text { standard devia- } \\
\text { tion }(n=3) \text {. }\end{array}$ \\
\hline \multirow[t]{2}{*}{50000} & before & $32.0 \pm 1.9$ & $30.1 \pm 7.3$ & $10.1 \pm 2.2$ & $42.7 \pm 4.7$ & $42.9 \pm 3.9$ & \multirow{8}{*}{$\begin{array}{l}\text { Tab. } 1 \text { Mittelwerte } \pm \text { Standard- } \\
\text { abweichung }(n=3) \text {. }\end{array}$} \\
\hline & after & $25.8 \pm 2.5^{1}$ & $24.5 \pm 5.2$ & $9.5 \pm 2.4$ & $43.0 \pm 3.5$ & $42.7 \pm 2.7$ & \\
\hline \multirow[t]{2}{*}{15000} & before & $32.4 \pm 2.3$ & $37.1 \pm 3.4$ & $15.8 \pm 4.8$ & $44.2 \pm 1.1$ & $44.9 \pm 2.3$ & \\
\hline & after & $31.8 \pm 1.6$ & $35.0 \pm 3.5$ & $13.1 \pm 1.8$ & $43.0 \pm 5.8$ & $43.0 \pm 2.8$ & \\
\hline \multirow[t]{2}{*}{5000} & before & $32.4 \pm 2.4$ & $39.8 \pm 8.3$ & $12.5 \pm 1.1$ & $42.3 \pm 6.3$ & $44.5 \pm 7.1$ & \\
\hline & after & $35.8 \pm 2.2$ & $42.7 \pm 5.6$ & $9.7 \pm 2.0$ & $48.9 \pm 7.4$ & $48.2 \pm 3.7$ & \\
\hline culture & before & $34.2 \pm 1.8$ & $44.7 \pm 5.2$ & $16.9 \pm 4.9$ & $51.9 \pm 7.9$ & $49.0 \pm 11.3$ & \\
\hline medium & after & $35.6 \pm 2.4$ & $44.2 \pm 6.9$ & $15.6 \pm 5.9$ & $48.3 \pm 7.2$ & $47.5 \pm 8.6$ & \\
\hline
\end{tabular}

${ }^{1}$ Indicates significant differences $(\mathrm{p} \leq 0.05)$ of SNR after cell injection.

Zeigt signifikante Unterschiede $(\mathrm{p} \leq 0.05)$ der SNR nach Zellinjektion an.

ical MR system. In-vitro tests of the mouse imaging protocol with both sequences revealed a reliable detection of single co-labeled MSC in cell phantoms ( $\bullet$ Fig. 1b). Hence, it was an attempt of this study to visualize single cells in mice with shallow breathing due to anesthesia with ketamine / xylazine without respiratory gating. The subtle motion artifacts of abdominal organs were counterbalanced by increasing the number of acquisitions up to $n=4$. However, single MSC which were microscopically detected in different abdominal organs ( $\bullet$ Fig. 7) could only be visualized by in-vivo MR imaging in the kidneys which have an SNR comparable to that of the liver ( $\bullet$ Table 1 ) but are less affected by respiratory motion because of their retroperitoneal location. To improve the detection of single cells in other abdominal organs, respiratory gating should be used. This is a standard operation with the use of dedicated small animal MR systems and animal monitoring/gating devices. Thus, MR imaging of single iron oxide labeled cells in the liver has been 

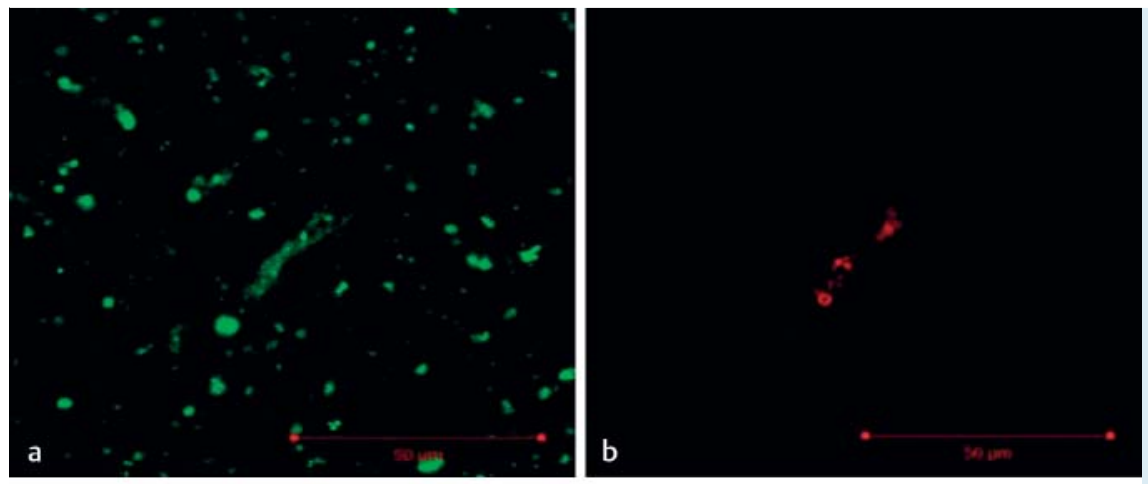

Fig. 8 Fluorescent and phase contrast confocal microscopy. CFSE stained cytoplasm a and iron oxide micro-particles $\mathbf{b}$ in corresponding localization clearly indicating a single MSC $\mathbf{d}$. Phase contrast microscopy showed trapping of the cell in nervous tissue of the brain c. Green autofluorescence is caused by axial scanning of neurofibers.
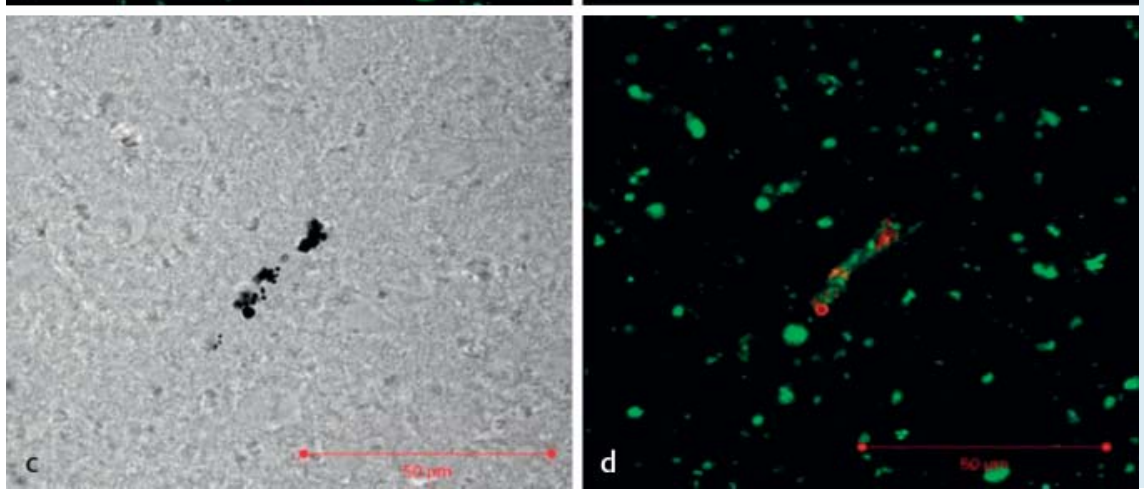

Abb. 8 Floureszenz- und Phasenkontrastkonfokalmikroskopie. CFSE gefärbtes Zytoplasma a und Eisenoxidmikropartikel $\mathbf{b}$ in korrespondierender Lage entsprechen eindeutig einer MSZ d. Die Phasenkontrastmikroskopie zeigt die Zelle in Nervengewebe des Hirns c. Die grüne Autofloureszenz wird durch axial getroffene Neurofibrillen erzeugt.

already demonstrated [13]. However, on clinical MR scanners the realization of respiratory gating for rodents (especially mice) is more challenging. The transformation of physiological signals from a mouse to be adequate for human scanners is a crucial point in terms of amplitude, frequency as well as vendor specifications. Therefore, respiratory gating of mice on human MR scanners remains challenging [46]. The ability to detect co-labeled MSC up to the single cell level in-vivo appears interesting to investigate homing and local engraftment of these cells because after systemic administration only a small percentage of transplanted MSC can be detected in the bone marrow and different organs [47]. In this study in-vivo imaging of single cells could be achieved by using a clinical 3.0T MR system and a commercially available mouse receiver coil. The total imaging time of 30 minutes per mouse which is easily covered by an intraperitoneal anesthesia with ketamine / xylazine makes this technique rather applicable to study also larger animal cohorts.

The co-labeling and MR imaging of MSC proposed in this study may be useful for experimental work in mice. However, translation of such techniques to high-resolution MRI in humans seems to be possible in the future. Already to date musculoskeletal MRI at 7.0 T can be carried out with a spatial resolution up to $156 \times 156 \times 500$ $\mu \mathrm{m}$ [48], which is in the range of the $2 \mathrm{D}$ GRE sequence applied for the abdominal imaging in mice. Furthermore, initial studies in patients receiving magnetically labeled cells using clinically approved iron oxide contrast agents have been reported $[49,50]$. These contrast agents may be also used to label MSC for single cell imaging [51]. Thus, homing of MSC might be visible on MRI in humans, for example after less invasive transplantation for cartilage repair [52]. A general limitation of this study was the use of murine cells only. Homing of human MSC in immunodeficient mice has been demonstrated $[47,53]$ and offers unique perspectives for in-vivo cell tracking studies in mouse models. The proposed co-labeling technique and MR imaging protocol are much likely also applicable to human MSC but have to be specifically investigated.
In conclusion, an efficient magnetic and fluorescent co-labeling of MSC that permits detection of MSC on a single cell level in mice by in-vivo MRI and histological validation was demonstrated. The technique was feasible using commercially available micron-sized iron oxide particles and a whole-body 3.0 T MR system equipped with a small animal receiver coil. Therefore, the described technique could be easily adopted by other groups for cell tracking of MSC in experimental studies.

\section{Clinical relevance of the study}

- Multipotent mesenchymal stromal cells (MSC) play a major role in regenerative processes such as the healing of bone fractures, tendon and cartilage damage as well as in the reconstitution process after stem cell transplant.

- To date, at least four clinical trials using MRI cell tracking with superparamagnetic iron oxides have been performed with promising results and it is most likely that MSC-based therapies will become more and more popular over the next decades.

- Co-labeling of MSC using fluorescent iron oxide particles combined with intracellular fluorescent cell membrane staining permits the in-vivo detection of single cells in experimental studies with a high correlation to histology.

- The established method therefore provides a platform for experimental monitoring of cell-based therapeutic approaches using clinical 3 T MRI, e.g. to monitor successful engraftment and recognize complications such as graft failure or tumor formation.

\section{References}

1 Anderson SA, Shukaliak-Quandt J, Jordan EK et al. Magnetic resonance imaging of labeled T-cells in a mouse model of multiple sclerosis. Ann Neurol 2004; 55: 654-659

2 Arbab AS, Pandit SD, Anderson SA et al. Magnetic resonance imaging and confocal microscopy studies of magnetically labeled endothelial 
progenitor cells trafficking to sites of tumor angiogenesis. Stem Cells 2006; 24: $671-678$

3 Bos C, Delmas Y, Desmouliere A et al. In vivo MR imaging of intravascularly injected magnetically labeled mesenchymal stem cells in rat kidney and liver. Radiology 2004; 233: 781 - 789

4 Shapiro EM, Gonzalez-Perez 0, Manuel Garcia-Verdugo J et al. Magnetic resonance imaging of the migration of neuronal precursors generated in the adult rodent brain. Neuroimage 2006; 32: 1150-1157

5 Heyn C, Ronald JA, Ramadan SS et al. In vivo MRI of cancer cell fate at the single-cell level in a mouse model of breast cancer metastasis to the brain. Magn Reson Med 2006; 56: 1001 - 1010

6 Fleige $G$, Seeberger F, Laux D et al. In vitro characterization of two different ultrasmall iron oxide particles for magnetic resonance cell tracking. Invest Radiol 2002; 37: $482-488$

7 Shapiro EM, Skrtic S, Koretsky AP. Sizing it up: cellular MRI using micron-sized iron oxide particles. Magn Reson Med 2005; 53: 329-338

8 Sipe JC, Filippi M, Martino G et al. Method for intracellular magnetic labeling of human mononuclear cells using approved iron contrast agents. Magn Reson Imaging 1999; 17: 1521 - 1523

9 Frank JA, Zywicke H, Jordan EK et al. Magnetic intracellular labeling of mammalian cells by combining (FDA-approved) superparamagnetic iron oxide MR contrast agents and commonly used transfection agents. Acad Radiol 2002; 9: S484 - S487

10 Sun R, Dittrich J, Le-Huu M et al. Physical and biological characterization of superparamagnetic iron oxide- and ultrasmall superparamagnetic iron oxide-labeled cells: a comparison. Invest Radiol 2005; 40: 504 -513

11 Foster-Gareau P, Heyn C, Alejski A et al. Imaging single mammalian cells with a 1.5 T clinical MRI scanner. Magn Reson Med 2003; 49: 968 - 971

12 Heyn C, Ronald JA, Mackenzie LT et al. In vivo magnetic resonance imaging of single cells in mouse brain with optical validation. Magn Reson Med 2006; 55: 23-29

13 Shapiro EM, Sharer K, Skrtic S et al. In vivo detection of single cells by MRI. Magn Reson Med 2006; 55: $242-249$

14 Dominici M, Le Blanc K, Mueller I et al. Minimal criteria for defining multipotent mesenchymal stromal cells. The International Society for Cellular Therapy position statement. Cytotherapy 2006; 8: 315 - 317

15 Grove JE, Bruscia E, Krause DS. Plasticity of bone marrow-derived stem cells. Stem Cells 2004; 22: $487-500$

16 Jaquet K, Krause KT, Denschel J et al. Reduction of myocardial scar size after implantation of mesenchymal stem cells in rats: what is the mechanism? Stem Cells Dev 2005; 14: 299-309

17 Morigi $M$, Introna $M$, Imberti $B$ et al. Human bone marrow mesenchymal stem cells accelerate recovery of acute renal injury and prolong survival in mice. Stem Cells 2008; 26: 2075-2082

18 Aggarwal S, Pittenger MF. Human mesenchymal stem cells modulate allogeneic immune cell responses. Blood 2005; 105: 1815-1822

19 Le BlancK. Immunomodulatory effects of fetal and adult mesenchymal stem cells. Cytotherapy 2003; 5: 485 - 489

20 McIntosh K, Zvonic S, Garrett S et al. The immunogenicity of human adipose-derived cells: temporal changes in vitro. Stem Cells 2006; 4: $1246-1253$

21 McTaggart SJ, Atkinson K. Mesenchymal stem cells: immunobiology and therapeutic potential in kidney disease. Nephrology (Carlton) 2007; 12: 44-52

22 Lange C, Brunswig-Spickenheier B, Cappallo-Obermann H et al. Radiation rescue: mesenchymal stromal cells protect from lethal irradiation. PLoS One 2011; 5: e14486

23 Koc ON, Gerson SL, Cooper BW et al. Rapid hematopoietic recovery after coinfusion of autologous-blood stem cells and culture-expanded marrow mesenchymal stem cells in advanced breast cancer patients receiving high-dose chemotherapy. J Clin Oncol 2000; 18: 307-316

24 Falagna V, Chartier M, Yufit T et al. Autologous Bone Marrow-Derived Cultured Mesenchymal Stem Cells Dilivered in a Fibrin Spray Accelerate Healing in Murine and Human Cutaneous Wounds. Tissue Engineering 2007; 13: $1299-1312$

25 Bruder SP, Jaiswal N, Ricalton NS et al. Mesenchymal stem cells in osteobiology and applied bone regeneration. Clin Orthop Relat Res 1998: S247-S256

26 Johnstone B, Yoo JU. Autologous mesenchymal progenitor cells in articular cartilage repair. Clin Orthop Relat Res 1999: S156-S162

27 Young RG, Butler DL, Weber W et al. Use of mesenchymal stem cells in a collagen matrix for Achilles tendon repair. J Orthop Res 1998; 16: $406-413$

28 Karussis D, Karageorgiou C, Vaknin-Dembinsky A et al. Safety and immunological effects of mesenchymal stem cell transplantation in pa- tients with multiple sclerosis and amyotrophic lateral sclerosis. Arch Neurol 2010; 67: 1187-1194

29 Dexter TM, Allen TD, Lajtha LG. Conditions controlling the proliferation of haemopoietic stem cells in vitro. J Cell Physiol 1977; 91: 335 - 344

30 Gordon MY, Clarke D, Atkinson J et al. Hemopoietic progenitor cell binding to the stromal microenvironment in vitro. Exp Hematol 1990; 18: $837-842$

31 Weimar IS, Miranda N, Muller EJ et al. Hepatocyte growth factor/scatter factor (HGF/SF) is produced by human bone marrow stromal cells and promotes proliferation, adhesion and survival of human hematopoietic progenitor cells (CD34+). Exp Hematol 1998; 26: 885 - 894

32 Hauger O, Frost EE, van Heeswijk $R$ et al. MR evaluation of the glomerular homing of magnetically labeled mesenchymal stem cells in a rat model of nephropathy. Radiology 2006; 238: 200-210

33 Ittrich $H$, Lange $C$, Togel $F$ et al. In vivo magnetic resonance imaging of iron oxide-labeled, arterially-injected mesenchymal stem cells in kidneys of rats with acute ischemic kidney injury: detection and monitoring at 3T. J Magn Reson Imaging 2007; 25: 1179-1191

34 Kraitchman DL, Heldman AW, Atalar E et al. In vivo magnetic resonance imaging of mesenchymal stem cells in myocardial infarction. Circulation 2003; 107: 2290 - 2293

35 Bulte JW. In vivo MRI cell tracking: clinical studies. Am J Roentgenol Am J Roentgenol 2009; 193: 314 - 325

36 Bulte JW. Science to practice: can stem cells be labeled inside the body instead of outside? Radiology 2013; 8: e74658

37 Khurana A, Chapelin F, Beck G et al. Iron administration before stem cell harvest enables MR imaging tracking after transplantation. Radiology 2013; 269: 186 - 197

38 Schrepfer S, Deuse T, Lange C et al. Simplified protocol to isolate, purify, and culture expand mesenchymal stem cells. Stem Cells Dev 2007; 16: $105-107$

39 Lange C, Schroeder J, Lioznov MV et al. High-potential human mesenchymal stem cells. Stem Cells Dev 2005; 14: 70-80

40 Shapiro EM, Skrtic S, Sharer K et al. MRI detection of single particles for cellular imaging. Proc Natl Acad Sci USA 2004; 101: 10901 - 10906

41 Arbab AS, Yocum GT, Kalish $H$ et al. Efficient magnetic cell labeling with protamine sulphate complaxed to ferumoxides for cellular MRI. Blood 2004; 104: 1217-1223

42 Kostura L, Kraitchman DL, Mackay AM et al. Feridex labeling of mesenchymal stem cells inhibits chondrogenesis but not adipogenesis or osteogenesis. NMR Biomed 2004; 17: 513-517

43 Ittrich $H$, Lange $C$, Dahnke $H$ et al. [Labeling of mesenchymal stem cells with different superparamagnetic particles of iron oxide and detectability with MRI at 3T]. Fortschr Röntgenstr 2005; 177: 1151 - 1163

44 Schrepfer S, Deuse T, Reichenspurner $H$ et al. Stem cell transplantation: the lung barrier. Transplant Proc 2007; 39: 573-576

45 Springer ML, Sievers RE, Viswanathan MN et al. Closed-chest cell injections into mouse myocardium guided by high-resolution echocardiography. Am J Physiol Heart Circ Physiol 2005; 289: H1307 - H1314

46 Inderbitzin D, Stoupis $C$, Sidler D et al. Abdominal magnetic resonance imaging in small rodents using a clinical 1.5 T MR scanner. Methods 2007; 43: 46-53

47 Bensidhoum $M$, Chapel A, Francois $S$ et al. Homing of in vitro expanded Stro-1- or Stro-1+ human mesenchymal stem cells into the NOD/SCID mouse and their role in supporting human CD34 cell engraftment. Blood 2004; 103: 3313 - 3319

48 Krug R, Stehling C, Kelley DA et al. Imaging of the musculoskeletal system in vivo using ultra-high field magnetic resonance at $7 \mathrm{~T}$. Invest Radiol 2009; 44: 613-618

49 de Vries IJ, Lesterhuis WJ, Barentsz JO et al. Magnetic resonance tracking of dendritic cells in melanoma patients for monitoring of cellular therapy. Nature Biotechnology 2005; 23: 1407-1413

50 Toso C, Vallee JP, Moral P et al. Clinical magnetic resonance imaging of pancreatic islet grafts after iron nanoparticle labeling. Am J Transplant 2008; 8: $701-706$

51 Peldschus K, Kaul M, Lange C et al. Magnetic resonance imaging of single SPIO labeled mesenchymal stem cells at 3 Tesla. Fortschr Röntgenstr 2007; 179: 473-479

52 Koga H, Engebretsen L, Brinchmann JE et al. Mesenchymal stem cellbased therapy for cartilage repair: a review. Knee Surg Sports Traumatol Arthrosc 2009; 17: 1289-1297

53 Erices AA, Allers CI, Conget PA et al. Human cord blood-derived mesenchymal stem cells home and survive in the marrow of immunodeficient mice after systemic infusion. Cell Transplant 2003; 12: 555 56124 